\title{
Experiencing, Knowing, and Building Architecture
}

\author{
By Rui Manuel Reis Alves*
}

Introducing the theme of experiencing, knowing and building architecture necessarily departs from key references outside architecture's realm. The studies of António Damásio ${ }^{1}$ on the link and interdependence between mind and body, and the influence of the instinctive and body mechanisms over rational processes - namely in what it relates to the creative process (J. A. Marina) $)^{2}$ - as well as the body of knowledge on the phenomenology of perception by Merleau-Ponty, ${ }^{3}$ are then the core sources of my positing: architecture, being a physical and mental phenomenon and a mind-body experience, becomes a reflection of how the human being connects to the outside world; it delivers visibility to what remains otherwise concealed in other areas of knowledge - perhaps due to a tendency to simplify conceptual models throughout the creative process in architecture. Whereas other areas of knowledge are traditionally linked to rationality and science, or intuition and arts, architecture's creative process was always hazily thought about or deemed 'confusing'. Taking into account the references above, we can say that architecture's creative process - or a project-geared reasoning - is not in essence different from other disciplines. What differs is the object and work processes. Relating both rational and instinctive processes in the 'creative act' is then found to be part of the interplay between the memory of sensorial images and lived images. This leads me to highlight the importance of sensitive experience in both the practice and teaching of architecture - in sum, sensitive experience is here thought as the foundation for creative memory and creative inquiry or, in other words, real knowledge. A number of projects will be used to examine in depth what I have posited above. With selected works of Álvaro Siza, ${ }^{4}$ Steven Holl, ${ }^{5}$ Peter Zumthor, ${ }^{6}$ and Le Corbusier, I will try to illustrate this apparent

*Assistant Professor /Research Fellow, Lusíada University, Lisbon / CITAD, Lusíada University, Lisbon, Portugal.

1. António Damásio (1944), Portuguese neuroscientist, professor and researcher at University of Southerm Califórnia, Known for his studies on the brain and human emotions. Major works include O erro de Descartes (1994), O sentimento de si (2000), and Ao encontro de Espinosa (2003).

2. José Antonio Marina Torres (1939) Spanish philosopher. Author of the theory of creative intelligence and one of the main thinkers to put forward the cultural paradigm of "ultra-modernity".

3. Maurice Merleau-Ponty (1908-1961), French philosopher of the phenomenology strand. Merleau-Ponty was a high-school teacher before WWII during which he served in the French army. He became a professor at Université de Lyon in 1945 and, from 1949, at Sorbonne. Influenced by Edmund Husserl, however, always grounding his theory on the body and perception. Author of Phénoménologie de la perception (1945), Le visible et l'invisible (1964), and L'oeil et l'esprit (1985).

4. Álvaro Siza Vieira (1933), Portuguese architect, many times awarded, including the Pritzker Prize in 1992 and the RIBA Medal in 2009. Author of many projects in Portugal, Spain, Germany, Holand, Italy, and Brazil, of which we highlight: the Malagueira neighbourhood in Évora (1977), Schlesisches Tor in Berlin (1984), a neighbourhood in the Hague (1988), urban rehabilitation of the blaze-hit historical district of Chiado in Lisbon (1988), Serralves Museum in Oporto (1999), Portugal Pavilion Expo98 Lisbon, The Galician Museum of Contemporary Art in Santiago de Compostela (1993), and the Iberê Camargo Foundation in Porto Alegre, Brazil (2008).

5. Steven Holl (1947) American architect. He has remarkable work has an architect, like the addition to the Nelson-Atkins Museum of Art (2007), Kansas City, Missouri, the Kiasma Museum (1998), Helsinki, the Chapel of St. Ignatius (1997), Seattle University; but he also has written works like Questions of Perception, Phenomenology of Architecture (1994), he wrote with Juhani 
dance between lived images and memory levels vis-à-vis the rational-instinctive and bodymental process of experiencing, knowing and building architecture.

\section{Initial Considerations}

The notion that the body is dependent of a mental existence seems to influence the separation of the 'mental' process of designing and interpreting architecture from the more physical processes, be it construction, or the more immediate confrontation of the human body with the 'built mass' of a building or site. Here, we resort to 'built mass' once it is directly and firstly presented to us before any other aspects such as light and configured space, for instance.

Indeed, the value placed on architecture as a physical object was never made secondary - large scale buildings or built landscapes have always been 'impressive'. However, mental and physical processes eventually became more disjoined. In a way, mirroring the changing role of the architect - one that designs but does not build - that in no doubt accompanied the separation of the design act from the construction process, a proclivity brought about by the Modern Era. Generally, this historic evolution resulted in the clustering of conceptual disciplines around the design process - drawing, perspective, projections, geometry, and the emergence of architects of the un-materialised among which Giovanni Battista Piranesi was the most paradigmatic example. These developments accompanied a technological evolution and the specialisation of the so called construction sciences which, in their own category, also went through the separation of knowledge from execution.

Engineers became the holders of technical knowledge whereas architects were tasked with architecture's artistic conception once architecture was considered one of the Beaux Arts.

This Cartesian conception underpins the separation, in architecture, of thought or idea (the abstract, mental process) from everything concerning the body (the human figure and its extension). Hence, construction and space were thought as a consequence of the idea.

Descartes himself, to demonstrate the veracity of deductive reasoning - the ordering from premise to conclusion in a sequence of linear logic - resorted to thoughts of mathematics and geometry.

Sensory experience became largely undervalued vis-à-vis the ideal construction - the 'truly' abstract process in architecture (geometry and metrics) were thus singled out from anything linked to the senses. The value of architectonic creation was placed only in those aspects closer to the idea.

The notion of 'architectural space' first articulated in the XIX century ${ }^{7}$ and further developed throughout the 1900 s did not interfere with this proclivity to

Pallasmaa and Alberto Pérez-Gómez. He is also a watercolorist.

6. Peter Zumthor (1943) Swiss architect. Selected works: Thermes of Vals (1996) and Kunsthaus Bregenz (1997). Awarded with the Pritzker Prize 2009.

7. Prominently in the theory of space by German art historian August Schmarzow (18531936) first voiced in the 1894 - A. Schmarzow, Das Wesen der Architektonischen Schöpfung (Leipzig: Karl W. Hiersemann, 1894); and also in Alois Riegl's treatise - A. Riegl, Die 
value architecture's geometric nature over its sensory materiality and qualitative experience. Louis Sullivan's own words conveyed this platonic and Cartesian conception when he stated not be troubled with the eventual physical disappearance of his works because "It is only the ideas that count." 8

However, phenomenology and the much later research developed by neuroscientists, prominently by António Damásio, came to challenge that long held duality.

Now, this fact was long known in the natural sciences - mind was related with brain activity and it was long understood that the body homes the brain and there is a mutual interaction. By bringing new insights about how the body influences mental processes, the work of Damásio greatly helped to place such dual conception on the spotlight - conception which, however, continues in the present.

We can draw a parallel with architecture. Beyond the exposed relation between architecture as an abstract construct vis-à-vis built-architecture (and also the relation of thought and the sensory experience of architecture) it is not surprising the hold of such duality. In addition, the value placed on the confrontation of the human body with the built landscape or object is often overlooked whereas image and virtual representation are strongly highlighted.

Souto de Moura once said that the thought in architectonic design is not a conceptual one ${ }^{9}$ - I endorse his stance. Indeed, if we cannot disentangle the mental process from the physical or bodily experience of architecture then, in the same way, we cannot think architecture independently from its material reality - as an artefact, or construction. Although there is a conceptual part in the design of architecture but, even so, it stays related with the sensory realm.

These two aspects are not always found in perfect balance in an architecture object. Other architects place more value in logic and the intellect and much less in the sensory experience and perception.

"Le Corbusier is one of the few architects who never suppressed the call of the senses and thought. He always kept both in a balance and, in that way though we can find this with other architects too - while the intellect civilises the sensory part, the latter actualises 'civility'. That is his most salient message. Precisely, the conceptual argument never suffices as a pretext. It always needs to be re-interpreted anew in light of its perceptive aspects."10

Spätrömische Kunst-Industrie nach den Funden in Österreich-Ungarn (Wien: Österr Archäologisches Institut, 1901). This idea of an (interior) architectonic space, highly significant for architecture throughout the XX century, considered the three dimensions but not the moving body in space.

8. A. Zaera, "Entrevista com Steven Holl," in El Croquis, ISSN 0212-5683.78 (1996), 13.

9. Interview to the Público newspaper in the $90 \mathrm{~s}$.

10. C. Rowe, "La Tourette," in Manierismo y Arquitectura Moderna y Otros Escritos (Barcelona: Gustavo Gili, 1950), 189. 


\section{The Body Homes the Mind: The Body's Influence over Mental Mechanisms}

In his works, ${ }^{11}$ António Damásio has demonstrated his thesis according to which, and contrary to traditional conception, we cannot consider mind and body as separate entities - if the body and brain constitute one single organism, we can then say that the mind is in the body more so than in the brain; consequently, the mental process is a biologic one as other biologic processes in that same organism and, as these, shares the same objective: first and foremost, to survive and maintain the body's wellbeing.

Therefore, the body strongly influences the mind's contents while the opposite seems to be less relevant. We have to consider, however, a certain autonomy of the mind which remains as if 'inaccessible' to the body - we can recognise the existence of a mental process that is, to some extent, independent from the environment and body; although, again, even this stems from the human organism interacting with the surroundings, in other words, this is the make-up of mental images being formed through perception. These images are recalled through memory and, to their reconfiguration, we call imagination.

Memory and imagination are closely linked processes: both depend on the ability to reconstruct mental images from mechanisms imprinted in the mind at the moment of perceptive experience - something Damásio calls "neural patterns."12 Damásio explains that every mental image leaves an imprint and this becomes the true repertoire of our knowledge-formation - it stays dormant waiting to be activated by one or other trigger. Knowledge is both innate - instinctive, corresponding to the body's regulatory mechanisms existing at the inferior levels of the brain - and acquired - in this case, neural patterns are located in the upper levels of the brain.

Imagination is then the possibility to reconfigure or relate the summoned images - to relate involves both rational processes and involuntary ones in what Damásio terms "somatic markers." 13 In Damásio's thesis, memory constitutes the essential mechanism, one of the most important capacities of the mind, essential to survival.

Moreover, the influence of the body upon the mind was found to be at the same level as the so called rational processes, namely when we choose and take decisions, and even when we create something. Creativity, if following Damásio, is enacted by memory and the "somatic markers" as they 'mark' our past experiences, be they positive or negative. They are activated or resurface by particular stimulus. Physiologic and mental reactions ensue and what emerges is what he calls a 'sentiment'.

And this the origin of intuition, ${ }^{14}$ fundamental in decision-making, choosing, or in all processes implicated with creativity - in particular, in the making of

11. A. Damásio, Descartes Error, Emotion, Reason and the Human Brain (New York: Avon Books, 1994); Damásio, Looking for Spinosa. Joy, Sorrow and the Feeling Brain (Boston: Houghton Mifflin Harcourt, 2003).

12. Damásio, Descartes Error, Emotion, Reason and the Human Brain, 1994.

13. Ibid.

14. Ibid. 
connections between apparently unrelated things or foreign something succeeding only by the action of "somatic markers". The latter are thus intimately linked to our personal experiences and the imprint left on us. Such process was developed for human survival and is constantly re-enacted for other purposes and in many functions.

For Steven Holl, in regards to architecture, the sensitive experience opens us to perception which then guides us to multiple, possible meanings. Perception allows us to reach an internal lifeworld and, through it, we can discover the sheer brightness of the outside world. ${ }^{15}$ Le Corbusier also made reference to something similar. In both, intuition is taken as the guide to that elusive internal world through which architecture is able to communicate meaning. Far from MerleauPonty's "raw knowledge" equated to perception, Holl differentiates architecture from pure phenomena based on the "intentionality" contained in the architectonic object.

\section{To Design: Discernment and Intuition}

"To a large degree, designing is based on understanding and establishing systems of order. Yet I believe that the essential substance of architecture we seek proceeds from feeling and insight. Precious moments of intuition result from patient work. With the sudden emergence of an inner image, a new line in a drawing, the whole design changes and is newly formulated within a fraction of a second. It is as if a powerful drug werw suddenly taking effect. Everything I knew before about the thing I am creating is flooded by a bright new light. I experience joy and passion, and something deep inside me seems to affirm: "I want to build this house!"16

In Peter Zumthor's account we can see that same mechanism described by Damásio. Even when the architect states that the design process is for the most part a rational task - to discern and to order - he comes around admitting that the true and key substance is emotion; in other words, a mechanism of physical, sensory, and bodily nature.

Peter Zumthor confirms the phenomenon, if you will. At times he finds himself "under the effect of some strange drug". For brief moments, rational control drops off...we're blindsided by the whole thing. Precisely in those moments, instead of disorder or disfiguring, the project is re-routed to another level of calibration, another level of meaning, all without the workings of any logical process. Perhaps could not be otherwise because, as Damásio explains, deductive logic is not sufficient to solve a problem whose variables are too complex or where data is incomplete.

This is nothing more than the same mechanisms which allow us to deliberate and choose in everyday life without a thorough analysis of every variable,

15. S. Holl, "Questions of Perception, Phenomenology of Architecture," in Questions of Perception, Phenomenology of Architecture (Tokyo: A+U Architecture and Urbanism, 1994), 40.

16. P. Zumthor, Thinking Architecture (Basel, Boston; Berlin: Birkhäuser, 1999), 20. 
otherwise we would be stranded and any choosing would be impossible. The same evolved mechanism allows us to make decisions based on incomplete data and relate things which would seem unrelated or foreign. This is the principle of intuition - results from the action of what Damasio calls "somatic markers" allowing us to summon former experiences in a quasi-automatic fashion. In all this, for the architect in that moment, there is a sort of 'clear insight' - to be on the brink of a solution to a problem always stirs passion and joy. Emotion, once again, guides us to know what is right.

Siza Vieira accounts that, before he jumps into any complex and thorough process of analysis say, of a complex functional programme and project, he immediately draws a sketch as soon as he gets an overall picture of the programme and site. ${ }^{17}$ It does not mean, however, that the solution is reached by intuition or otherwise casually; instead, what happens is the mind can make connections, sometimes surprising ones, and point out solutions based on incomplete information. Moreover, the more data we have the more difficult it becomes to find said solution. For that reason, the mind foreshortens the search with options to be tested and further confronted with the deductive process - complete data is not necessary at this point because stimulus help to summon those images stored in our memory through our lived experiences.

For the North-American architect Steven Holl, who normally identifies with Merleau-Ponty's phenomenology, the approach is quite different: in a conscious fashion, architecture is built from an idea or concept whose phenomenological potential he sets out to explore in the project and in built architecture. Singularly, a relation is established between the mental and physical aspects of architecture.

In the interpretation of any architectonic place, the first gauge of information is always disperse and place-bound. It juxtaposes and accumulates but, further, we are able to gradually elaborate a system of relations - the basis of a synthesis and understanding of the architectonic place as a whole. According to Steven Holl, the system of relations exiting in the architectonic place is something arrived at intentionally during the project and this can only be understood introspectively and intellectually.

For Holl, the crux of this process is in the subjective link (or inter-subjective, of who experiences and who designs) between perception and the conceptual logic guiding the project. This is the case in one of his most prominent works, the Kiasma Museum in Helsinki ${ }^{18}$ (Figure 1). Different concepts are here intersected, such as the concept of quiasma - the intertwine of body-world (Merleau-Ponty) symbolically related to the building's location in the city, and also the concept of parallax - a scientific notion taken by phenomenology to study the phenomenon of perception with the human body's movement in space -which manifest in the spatial experience of the interior intentionally putting us in a sort of unbalance with the distorted perspective of the slight folding of the walls and surfaces. ${ }^{19}$

17. A. Siza, "Il Progetto come Esperienza," in Domus. ISSN 0012 - 5377.746 (1993), 17.

18. The Kiasma Museum (built 1996-98, Helsinki) resulted from an architecture competition open to Nordic architects and to four specially invited international architects, among whom was Steven Holl who eventually won.

19. Holl, Parallax (Basel, Boston, Berlin: Birkhäuser, 2000). 
Steven Holl refers to his use of concepts - stemmed from various disciplines and symbolically mirrored in his architecture - as a method to stimulate his creativity and escape from a language of forms or what could turn into a shallow manipulation of formal repertoires. ${ }^{20}$

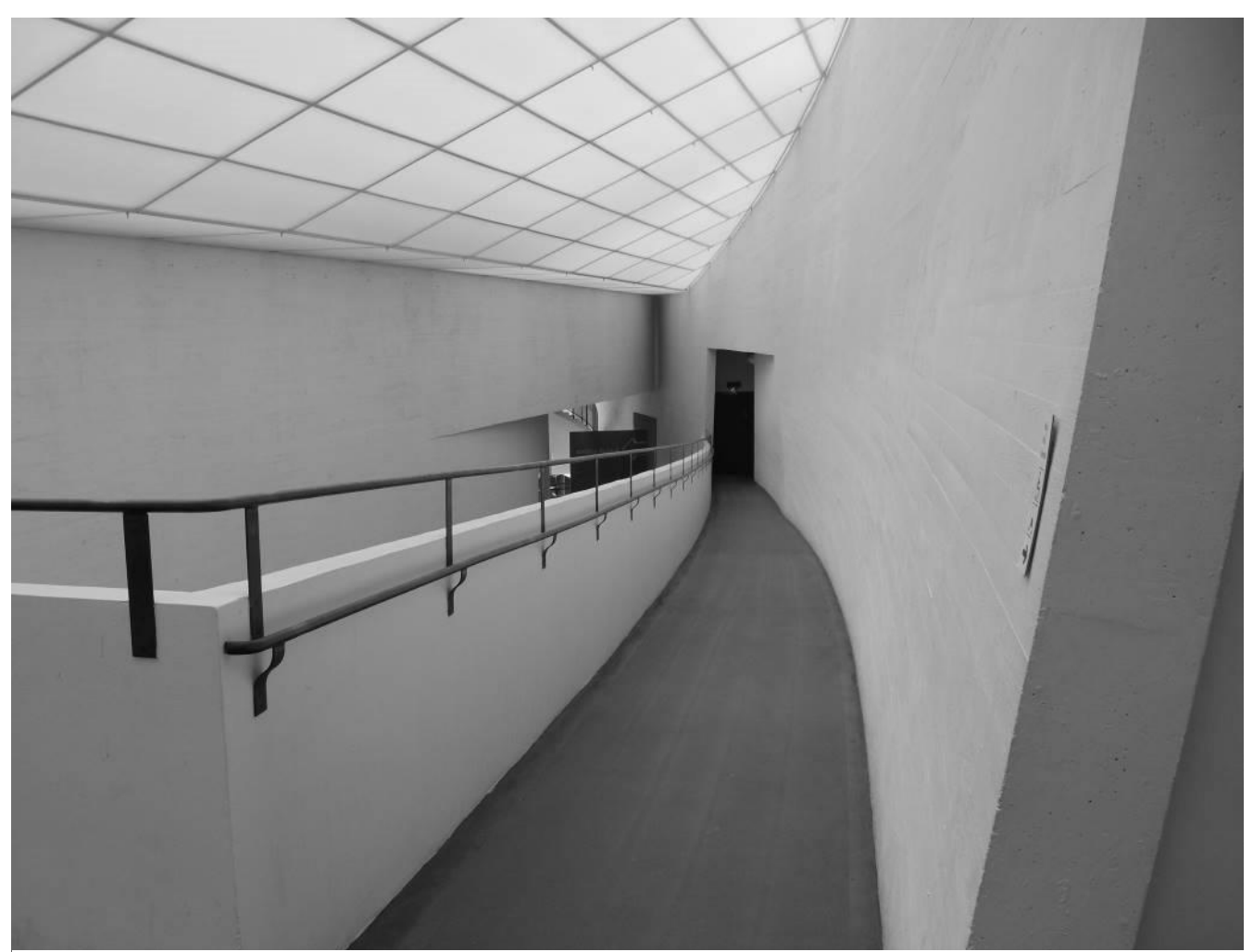

Figure 1. Interior of the Kiasma Museum (1996-98) in Helsinki, Finland. Steven Holl

Source: Author, 2009.

\section{The Mechanisms of Creativity and Architecture}

José António Marina ${ }^{21}$ articulated the relation between those mental processes and the mechanisms of creativity based the testimonies of writers, scientists, and artists as a case study. His findings show that it is possible to understand how, for us to make actual use of the mental processes subordinated to creativity; we need to use particular tools. The reason why we establish objectives, draw strategies, and search schemes and also why we feel the need to gauge results and redefine objectives throughout an often long creative process which, nevertheless, always advances in stages.

Marina $^{22}$ explained the relation between perception and creativity, also between the simplest mental tasks and the most complex. The way we approach

20. Zaera, Entrevista com Steven Holl, 1996, 6-31.

21. J. Marina, Teoria da Inteligência Criadora (Lisboa: Caminho, 1993).

22. Ibid. 
the world and worldly things - there lays the seed of creativity. In the most mundane action, such as sighting, looking at a random thing, begins the capacity to produce something extraordinary because, as Damásio ${ }^{23}$ put it, the imprints of mental images resulting from our interactions with the environment and the way we relate those images in accord to our experiences, constitutes our own-made knowledge.

We can relate Damásio's and Marina's theories with the experience of architecture and the processes that organise and stimulate creativity. At this point, based on their conclusions, we can understand that the mental processes enacted by the perception of an architecture object and also in its creation are not, in essence, different from those generally used in the perception of everyday events and creativity in any realm - the distinction lies in the work process and its object.

The so called 'architectonic thought' comprises the use of methods and specific instruments to attain a very precise objective - the architecture design. Beyond this, said 'thought' resorts to the same mental mechanisms that we all use in the everyday and infinitely adapt and re-work in varied creative tasks.

Proved, as it were, that mental activities are built from the relation between organism and environ, and also the influence of the body upon the mind, concurs with the positing of Merleau-Ponty ${ }^{24}$ - elaborating on the phenomenology strand, Merleau-Ponty suggested that perception constitutes the base of all reflection in the collusion of body and world. This presented a breakthrough from the traditional conception of Cartesian origin, particularly in regards to the belief of human subject and object as opposites. Even though Merleau-Ponty's questioning aimed at the essence of knowledge, his defence of the value of the senses of the body and our most basic relationships with the world, accords with Damásio's conclusions.

The different areas of the brain are deeply connected and work together. Moreover, there is dominance of the sensory processes (or mechanisms created from the body) over mental processes.

We have to consider, however, a certain autonomy of the mind which remains as if 'inaccessible' to the body - something we can perhaps call the domain of intelligible. Yet, the sensory (if designating the whole of mental processes related to the sensory system) exerts a key influence even in the more 'rationalised' processes, through what Damásio designates "somatic markers" - these can be equalled to "intuition".

According to Damásio, this is origin of creativity, i.e. the intuitive establishment of relations and connections between apparently unrelated things. Fundamental to artistic and scientific creation, creativity derives from processes originally developed for basic survival; the same are active beyond the fulfilment of basic needs as in the personal and social realms.

Thought is based on the permanent interaction of the organism with the environment. The latter feed the formation in the mind of images not just visual

23. Damásio, Descartes Error, Emotion, Reason and the Human Brain, 1994.

24. M. Merleau-Ponty, Phenomenology of Perception (London, New York: Routledge, 1945). 
ones but all across the five senses - these images are the basis of thoughts. In other words, every thought stems from images originated in the sensory system. They can also be built by the mind through those mechanisms activating neural patterns related to images formerly produced. In the summoning of images - by recalling or imagining - a reinterpretation of existent patterns takes place; such reinterpretation is always fed by images formed ex ante.

The mind produces images from the sensory system and also has the possibility to summon images from patterns previously formed in the brain.

The sensory system does not function without the brain or the mind (where images get to be formed). And so, the mind is dependent of the relation to the environment mediated by the sensory system (the basis of thought proper). The idea that the brain can function autonomously is, therefore, discarded.

None of these types of mental operations differ from the ones used by the architect throughout the design process. We have to acknowledge that the cornerstone of the capacity to think in architectonic terms is the capacity to form images of an essentially visual nature.

And yet architecture goes well beyond the strictly visual universe. Not least because sound and audition is involved (hence, audible images are formed or summoned when the architect is creating) but also because architecture calls for a tactile relation, both direct or indirect; for instance, the texture of walls and other surfaces, the materials, communicate tactile sensations through sight or through the movement of the body in space. However, visual images are prominent, the main structure to which other images of a different nature come to 'fit in' if you will.

The formation of sensory images is, according to Damásio, the basis of any type of reasoning. In that sense, the 'architectonic thought' does not differ from other thoughts - it is not a specific nor a particular type of thought.

In all likelihood, there are no specific thoughts for different knowledge areas as Marina puts it. ${ }^{25}$ All knowledge areas find support in the same mental processes. With that said, we can perhaps suggest that what might foster the capacity to think in more 'architectonic terms' is the build-up of an architectonic memory - to relate a hazy repertoire of images and to give structure to space becomes the key aspect of architectonic creation.

\section{Memory, Imagination, and the Architectural Design}

"When I concentrate on a specific site or place for which I am going to design a building, if I try to plumb its depths, its form, its history, and its sensuous qualities, images of other places start to invade this process of precise observation: images of places that I know and that once impressed me, images of ordinary or special places that I carry with me as inner visions of specific moods and qualities; images of architectural situations, wich emanate from the world of art, of films, theater or literature." 26

25. Marina, Teoria da Inteligência Criadora, 1993.

26. Zumthor, Thinking Architecture, 1999, 36. 
"If I lived this or that, then many things remained and then tend to show up again unconsciously. In the making of architecture many things come from the unconscious. Things that are part of us and lead us to search towards a particular direction. Our mind is also a storage accumulating more capacity the more it is used. In the case of the architect, this store-house is made of accumulated information, ever widening, of what you see and study. And what you see are cities, movies, paintings, people...

Literature, music, everything! Literature is so linked to music, to sculpture and painting, to ballet...Back in the day we would start with focusing on a person and his or her work. Afterwards, we would start to know more of this and that, to widen. At some point, we're not copying anything; we have some much information that it becomes part of us. Pops up when needed. Shows up because it is in us." 27

In both Zumthor e de Siza's accounts, we see the importance of memory as a recurring tool, a potent weapon in the arsenal of creativity. Science demonstrates memory to be the basis of intelligence. Brain functions - from directing body motions to perception and creative activity - imply a constant access of the mind to memory, to stored knowledge. Such knowledge can be so deep as if it is already "part of us", as Siza said. Further, it allows us to understand reality with different levels of depth according to our own knowledge and through mechanisms unware to us. It reconfigures constantly establishing new links in an act we can compare to digestion. The more 'usable', 'digested' knowledge, the more creative we get. Seemingly, this is the true source of human creativity.

For instance, Peter Zumthor speaks of personal experiences unrelated to architecture. Siza Vieira speaks of an initial interest about a character which he started to copy and how this 'trick' helped him to unfold and widen understandings and knowledge by, first, relating that character with other characters and situations.

27. A. Ribeiro, "Entrevista com Álvaro Siza," in Pública (5 Apr. 2009), 18. 


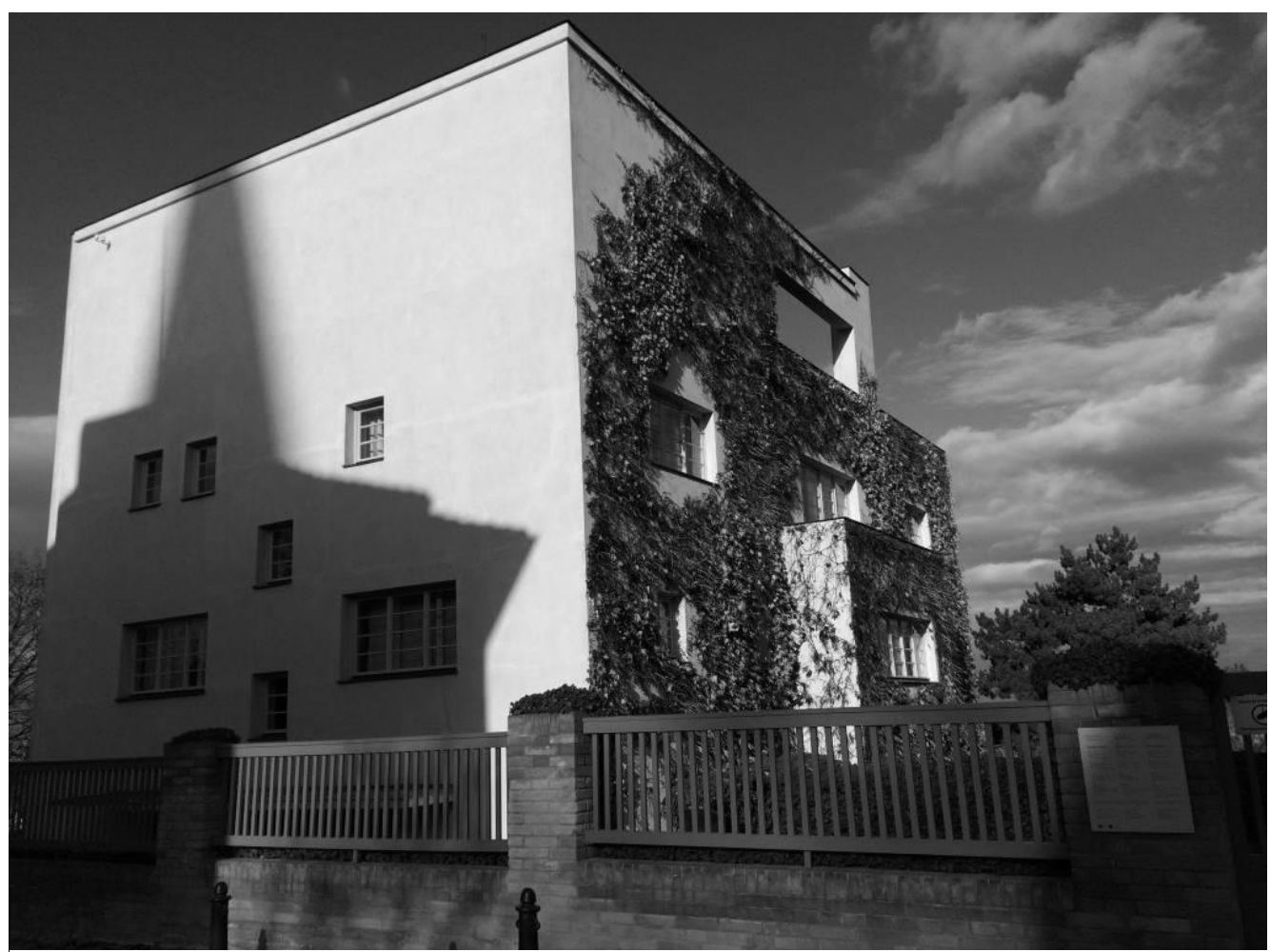

Figure 2. Exterior View of Villa Müller (1928-30) in Prague, Czech Republic. Adolf Loos

Source: Catarina Lampreia, 2014.

In both cases, one needs to know, understand, and experience. Knowledge has to imprint something in us, emotionally and rationally. It is possible, and many people attest to this, to understand some of Siza's memories of architecture even if transfigured or re-contextualised. At times this seems deliberate, consciously done, as if comments, critics, other times, they seem to come from less conscious territories.

To illustrate the first case, we can see a reference to Adolf Loos (Figure 2) in the Avelino Duarte House (Figure 3) designed by Siza in Ovar (1981-85); in the second, we find a relation, perhaps an unconscious link, between his School of Education Sciences in Setubal (1995) (Figure 4) and the old shrine of Cabo Espichel (Figure 5).

When asked about the similarity of his School in Setubal (Figure 1) built in the 90 s with the old shrine of the $18^{\text {th }}$ century only $40 \mathrm{~km}$ East (Figure 2), Siza said that it was so obvious although he never thought of it, at least not consciously. ${ }^{28}$ We can then infer that Siza's acquaintance with the spatial structure of the shrine lead him to adopt, even if not deliberately, that same structure not as a metaphor but instead as a syncretic parallel to, eventually, build another structure different from the shrine in almost everything except in its overall lines. But this circumventing and match was not consciously done. As he said, "I wasn't

28. M. Matos, "Inquirição a um Projecto," in Álvaro Siza (ed.) L. Trigueiros (Barcelona/ Lisboa: Gustavo Gili/Editorial Blau), 1995. 
copying" [although we cannot say the same about the house in Ovar]. Such information, if you will, is "already part of us. Pops up when needed. It shows up because it is in us." 29

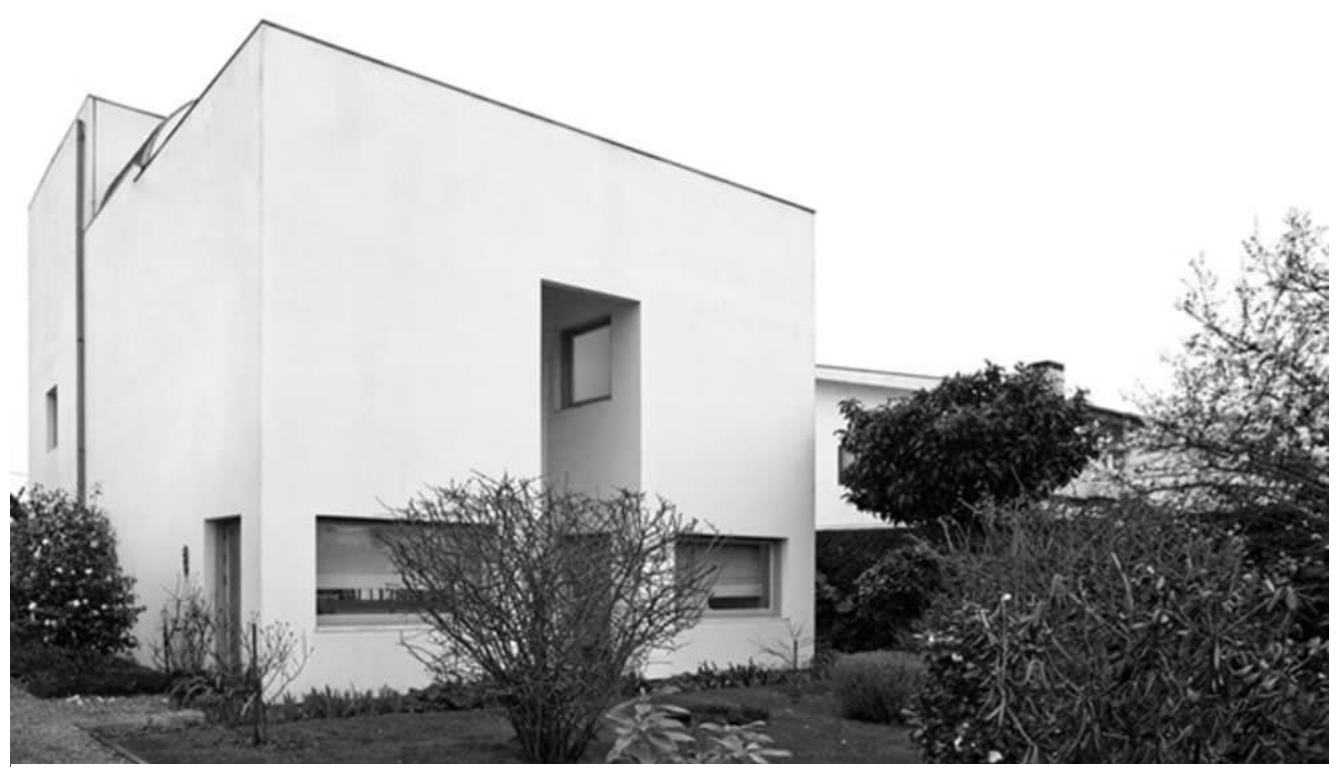

Figure 3. Exterior View of Casa Avelino Duarte (1981-85) in Ovar, Portugal. Álvaro Siza

Source: Fernando Guerra|FG+SG.

Le Corbusier once shared a similar account about how he would introduce the project's initial information in his head and then leave the mind to work on its own until, one day, the idea would find it way.

As we saw earlier, memory is the mind's ability to summon already lived, experienced images. There is creative capacity unattached to the possibility of relating visual or other type of images - "dispositional representations" existing in the brain boost such possibility. ${ }^{30}$ At the same time, these "dispositional representations" can only exist once we have experienced architecture emotionally and intensely enough to form a lasting impression.

Knowledge spurs from existent dispositional patterns able to generate mental images. In that sense, mental images of architectonic spaces are the raw material of architectonic thought.

However, as briefly mentioned earlier, those dispositional patterns allow us to produce beyond images.

29. Matos, "Inquirição a um Projecto," 1995.

30. Damásio, Descartes Error, Emotion, Reason and the Human Brain, 1994, 104-108. 


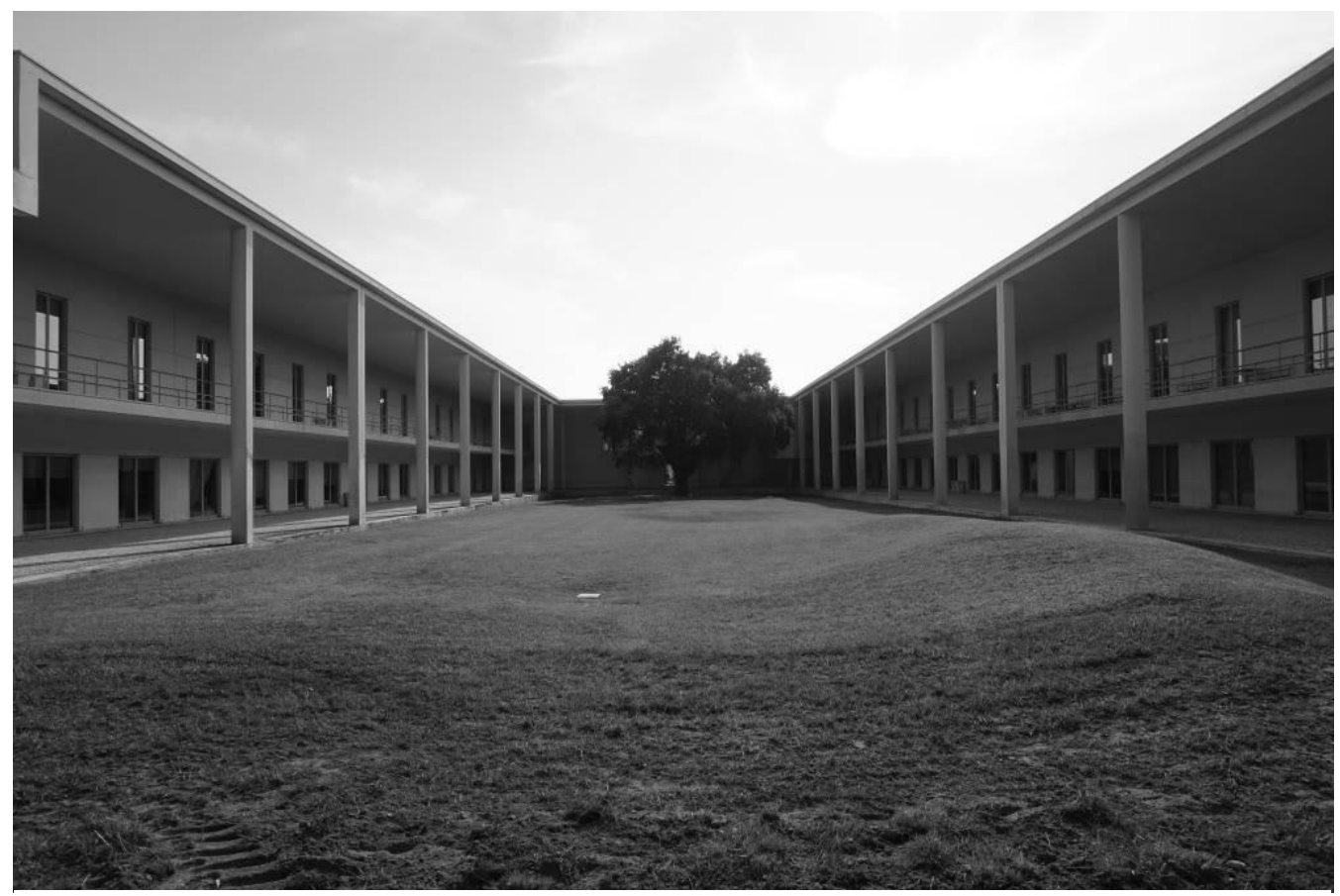

Figure 4. Exterior View of Escola Superior de Educação de Setúbal (1986-93) in Setúbal, Portugal. Álvaro Siza

Source: Author, 2018.

The very rules and strategies for the manipulation of said images ${ }^{31}$ are here enacted. Both stem from the understanding, in this case, of architectonic systems. Then, the experience of architecture is never limited to a sensory experience. It needs to rest on discernment and thorough understanding.

Damásio also refers to the existence of "somatic markers" associated to particular experiences, and which help us in complex decisions and choosing as is the case in any creative endeavour.

As a result, knowledge does not derive from a purely rational process. Quite the opposite. Emotion plays an important role when we relate things in whichever creative task is at hand and, of course, also saliently in the design process in architecture.

The role of emotion does not dismiss the importance of reflection in the creative process. Selecting and decisions do result from impulse alone. Reflection is fundamental for our discernment of lived experiences. More so in regards to architecture being as it is a complex realm of knowledge not only because of architecture's specific issues ${ }^{32}$ but also because of its increasingly elaborate relationship with other domains.

31. Damásio, Descartes Error, Emotion, Reason and the Human Brain, 1994, 104-108. 32. Marina, Teoria da Inteligência Criadora, 1993. 


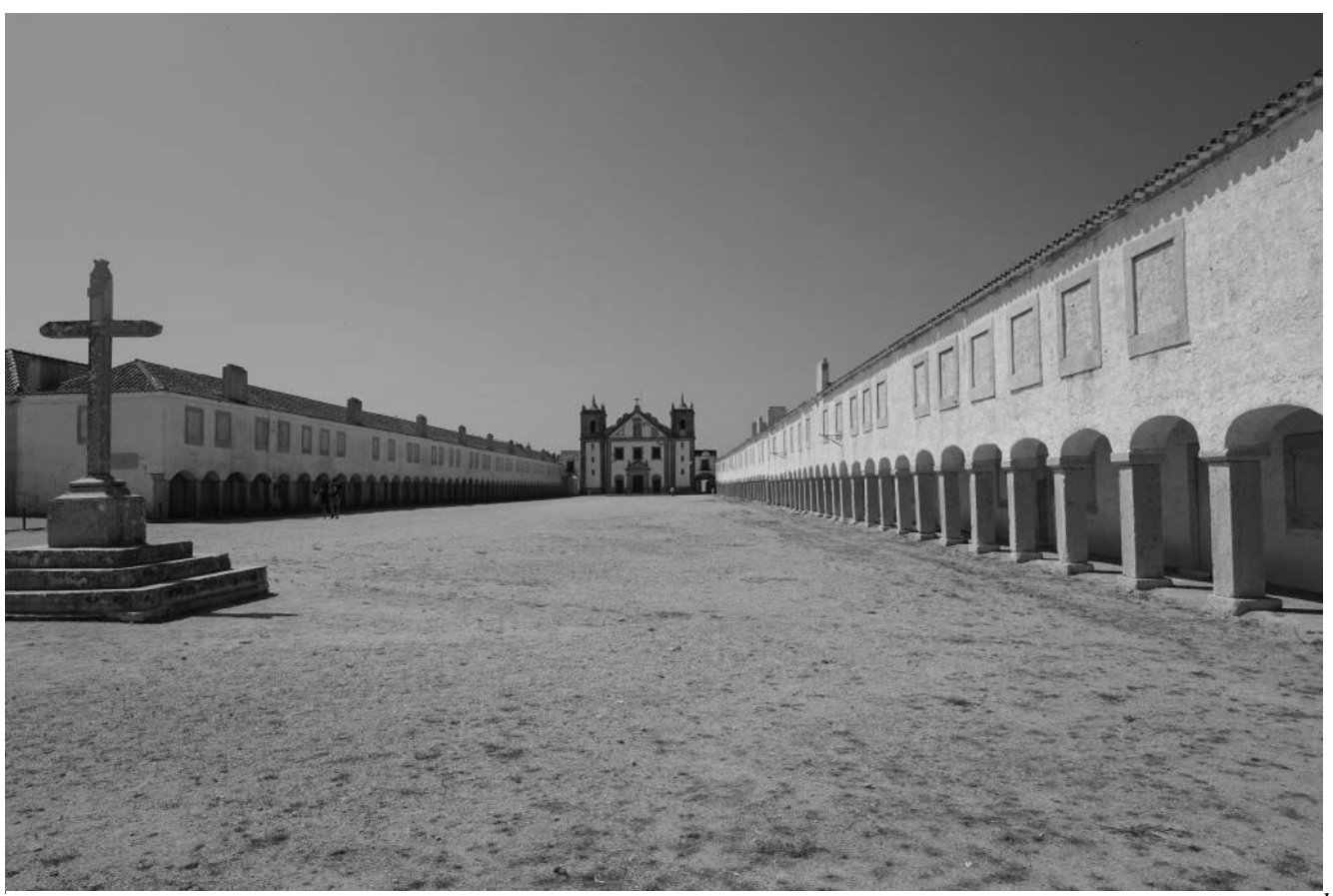

Figure 5. Exterior View of the Santuário de Nossa Senhora do Cabo (18 Century) in Cabo Espichel, Sesimbra, Portugal

Source: Author, 2018.

Architectonic thought cannot be simply equated to perception. Why? Because it convenes the use of logical and rational processes which help us to set objectives and to fine-tune and direct creativity. Architectonic thought is far from raw, as in only relating to the world through the senses as Merleau Ponty highlighted in regards to painting. ${ }^{33}$ As Marina explained, ${ }^{34}$ the creative process depends of the intuition and of a set of other processes feeding it with precise objectives, context, and the possibility of assessment - this occurs in architecture-making and other areas, in the arts and sciences.

How is this revealed throughout the design process? What is the role played by intuitive mechanisms and logical mechanisms throughout the project? Are there stages where any of these mechanisms seem to predominate?

All architects mention the starting phase - when they are confronted with the 'problem', with the functional programme, the site, and the budget - as a fuzzy period where any data input feeds a cloudy amalgam, something they cannot discern as a clear structure. Adding all the data just won't do. Sometimes, the more elements you add the more the problem blurs into a mass. Therefore, at this stage, observing and feeling are paramount.

33. Merleau-Ponty, "Eye and Mind," in The Primacy of Perception (Evaston: Northwestern University Press), 1960. 


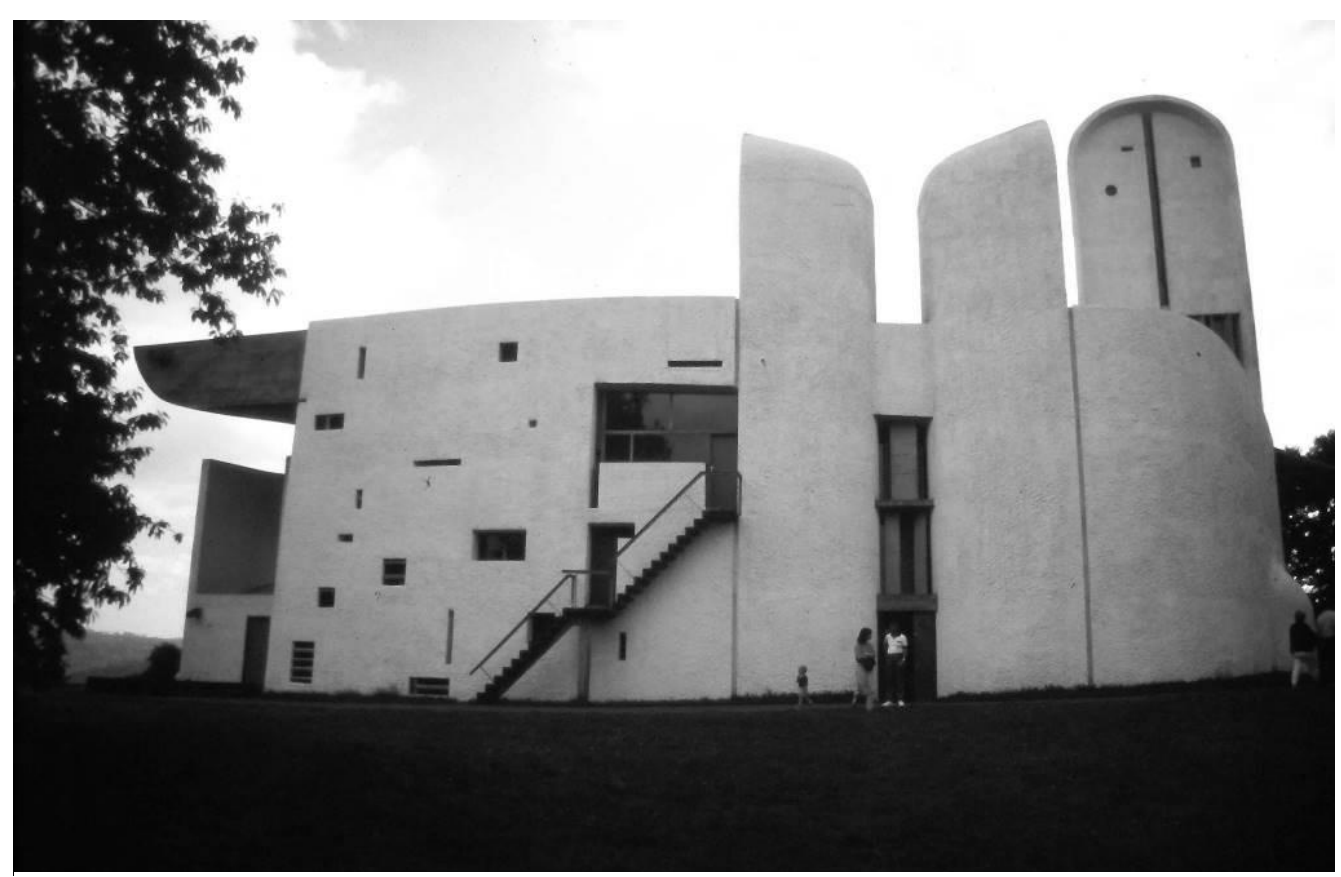

Figure 6. Exterior View of Notre-Dame-du-Haut (1950-55) in Ronchamp, France. Le Corbusier

Source: Author, 1991.

It is also a period when the architect is fully focused on the site. For Siza Vieira, for instance, the process of what we sometimes call in architecture schools "reading the site", is mainly an exercise of observation by drawing - to see in depth, to disassemble and relate, and also the gesture that seeks to match the visual thought; drawing makes visible our interpretation of what is observed. An elaborate process, no doubt, that leaves a mental imprint or "a pattern of disposition" if in Damásio's parlance. And, of course, the focus called for when one draws opens the door for this mark to build up well beyond the sheet of paper. On drawing we can elaborate further: it is process of interpreting the visible as mentioned. By sketching we discover the 'anatomy' of a certain place, its topography, skyline, light, horizons, lines, as if we start to recognise its 'face'.

Driven to survive, human beings are equipped with an innate ability to memorise and recognise the features of a territory as it occurs with recognising a human face. Why we recall or recognise places and faces from the past is more difficult to explain. This comes to show the almost automatic, instant fashion of visual recognition without resorting any logical reasoning. In drawing, because it implies interpretation, logic has to intervene.

Often we hear architects speaking about 'capturing the essence of the place', something one can only attain by 'feeling'. Le Corbusier used to say that for him to 'feel' the site where the Chapel of Notre-Dame-du-Haut (Figure 6) was to be built, he spent several hours strolling that land only to know the soil and the open horizons. ${ }^{35}$

35. Le Corbusier, Textes et Dessins pour Ronchamp (Ronchamp: Association CEuvre De Notre-Dame Du Haut, 1965), 9. 
This phase is followed by a period of meditation be it long or short. Also for Le Corbusier, it could mean months without a single sketch. During this time, many authors speak about leaving the mind work 'on its own' and also they do not try to influence this process logically or even consciously. Perhaps a time for the mind to summon images through those "patterns of disposition" registered in the brain tissue while these are being linked by "somatic markers".

We can thus assume that "neural registers" and "somatic markers" work together below the conscious level; gradually, from their conjoining, relations starts to emerge, both from past experiences and knowledge so as to generate connections - connections which intuition comes to relate to reach the solution most apt to solve a complex problem, be it an architecture project, a scientific, or philosophic question and so on.

Before I conclude, some questions and reflections can be drawn from what was said hitherto.

If indeed the mind is incorporated - that is, correlates and cannot be disjoined from the body and the sensory experience - then rational processes are permanently influenced by intuition. What does this say about the creative process in architecture? It tells us that, ultimately, the process and its material result reflect back this deeply human phenomenon. Architecture is thought for and created to be lived through a human body. It caters to a body with a mind, a body that thinks and feels.

Isn't architecture, first and foremost, a construction resulting from the interaction of body and mind in a surrounding environment? Is it not architecture after all a meticulously, rationally constructed image, carefully ordered? Is it not architecture this undoubtedly logical construct where desires, impulses, intuitions and all the gestures of creative freedom of the author(s) come to be reflected on? Does the same occur, albeit differently, with those who use this architecture?

When architects design, they make intense use of memory, they summon their references, architecture situations they know, the works of authors they follow, etc. Architects come to use logical-deductive processes as they seek an order, a geometry. Resorting to technical knowledge of construction, they organise and shape space. In this extended act, and as in other creative acts, mind is one with the body, the latter stimulates the former: our bodily experience stimulates and influences our thoughts. What we lived and experienced during the course of our lives is constantly summoned and, each time, things get reconstructed and assembled with other images and new patterns ensue. Memory is a dynamic mechanism and the origin of imagination. Jointly with mental images (that is, not necessarily of a visual nature) we learn the mechanisms of its use and these are also images.

The learning process in architecture - as in any other creative area of comparable complexity - develops in the long-haul in order for a sort of mental (and sensory) reconstruction to occur from acquired knowledge, particularly on architecture, as forming a cultural basis but also as lived experience and perceptive engagement - in short, a wealth of true knowledge needs to consolidate. 


\section{Conclusions}

I conclude by highlighting the three key points developed in this presentation.

1. The findings of neuroscientist António Damásio bring new insights to the way we understand the creative process in architecture. Namely, the fundamental influence of the body over the mind, and also the relation between creativity and memory. Both are paramount to unveil how architectonic imagination and knowledge come together in the design act. The influence of emotions in decision-making is enacted by a mechanism which we can identify with intuition - we are then equipped to foreshorten connections between apparently unrelated things and this is unconsciously done. Such mechanism is the basis of creativity and feeds from the summoning of images stored deep in our memory, somehow marked by our experiences and emotional responses.

2. The mental processes called in the perception of architecture, and in its creation, do not differ from those we use in the everyday and in other creative tasks whatever their domain. It is then a particular attention to architecture (a perceptive focus if you will) that comes to change the very perception of space. The depth and width of architectonic culture alters the richness and operative ability of memory. Further, Marina's conclusions underline how creativity is a vital, biologic process which we re-utilise for varied purposes and at times directed for a particular objective, as is the final result of designing an architectonic object. For this to occur, we find the need to set stages, objectives and strategies in order to make operative the capacity which we all have but need to find avenues to use it for this or that end.

3. The accounts and works of four well-known architects were taken as case studies. Here, we understood how sensory mechanisms are put at work and how these are indelibly linked to memory, particularly the memory resulting from experiences that impacted our mind and senses. This memory keeps expanding, reconstructing as it forms the basis for creativity. There is no creativity without memory. Memory is marked by emotions, by what the body feels and imprints on the mind. We thus resort to a sort of 'deep pond' of mental images to design architecture. Awareness of these processes helps to bring to the fore the importance of direct, sensory experience in the creation of architecture and also how it is learned and taught. And here the path is open for further research.

\section{Acknowledgments}

This work is financed by national funds by FCT - Foundation for Science and Technology under the Project UID/AUR/04026/2013. The author wishes to thank Fernando Guerra $\mid \mathrm{FG}+\mathrm{SG}$ for the use of the photograph of the Avelino Duarte House, in Ovar and to Catarina Lampreia for the use of the photograph of Müller House in Prague. 


\section{Bibliography}

Damásio, A. Descartes Error, Emotion, Reason and the Human Brain. New York: Avon Books, 1994.

. Looking for Spinosa. Joy, Sorrow and the Feeling Brain. Boston: Houghton Mifflin Harcourt, 2003.

Holl, S. "Questions of Perception, Phenomenology of Architecture." In Questions of Perception, Phenomenology of Architecture. Tokyo: A+U Architecture and Urbanism, 1994.

. Parallax. Basel, Boston, Berlin: Birkhäuser, 2000.

Le Corbusier. Textes et Dessins pour Ronchamp. [Texts and Drawings for Ronchamp.] Ronchamp: Association Euvre De Notre-Dame Du Haut, 1965.

Marina, J. Teoria da Inteligência Criadora. [Theory of Creative Intelligence.] Lisboa: Caminho, 1993.

Matos, M. "Inquirição a um Projecto." [Inquiry to a Project.] In Álvaro Siza. Edited by L. Trigueiros. Barcelona/Lisboa: Gustavo Gili/Editorial Blau, 1995.

Merleau-Ponty, M. Phenomenology of Perception. London, New York: Routledge, 1945. . "Eye and Mind." In The Primacy of Perception. Evaston: Northwestern University Press, 1960.

Ribeiro, A. "Entrevista com Álvaro Siza." [Interview with Álvaro Siza.] In Pública (5 Apr. 2009), 12-21.

Riegl, A. Die Spätrömische Kunst-Industrie nach den Funden in Österreich-Ungarn. [The Late Roman Art Industry after the Finds in Austria-Ungary.] Wien: Österr Archäologisches Institut, 1901.

Rowe, C. "La Tourette." In Manierismo y Arquitectura Moderna y Otros Escritos. Barcelona: Gustavo Gili, 1950.

Schmarzow, A. Das Wesen der Architektonischen Schöpfung. [The Essence of Architectural Creation.] Leipzig: Karl W. Hiersemann, 1894.

Siza, A. "Il Progetto come Esperienza." [The Project as an Experience.] In Domus. ISSN 0012 - 5377. 746 (1993): 18-22.

Zaera, A. "Entrevista com Steven Holl.” [Interview with Steven Holl.] In El croquis. ISSN 0212-5683. 78 (1996), 6-31.

Zumthor, P. Thinking Architecture. Basel, Boston; Berlin: Birkhäuser, 1999. 